\title{
DA CONCESSÃO DE FINANCIAMENTO AOS ESTADOS, AO DISTRITO FEDERAL E AOS MUNICÍPIOS POR INSTITUIÇÃO FINANCEIRA FEDERAL
}

Henrique Chain Costa

Graduado em Direito pela Universidade Estadual do Rio de Janeiro (UERJ). Pós-graduação lato sensu em Direito Constitucional pela Universidade Anhanguera. Atua há mais de onze anos na Administração Pública Federal, primeiro como advogado de contencioso das Centrais Elétricas Brasileiras - ELETROBRÁS e atualmente como advogado da Financiadora de Estudos e Projetos - Finep, onde exerce a função de

Coordenador de Padronização da Superintendência Jurídica.

Rafael Roberto Hage Tonetti

Graduado em Direito pela Faculdade de Direito da Universidade de São Paulo (USP). Possui especialização em Direito Tributário pela mesma Universidade. Atua há quatro anos na Administração Pública Federal como advogado da Financiadora de Estudos e Projetos Finep, onde atualmente exerce a função de Gerente Jurídico da Diretoria Financeira. Anteriormente à Finep, exerceu a advocacia na iniciativa privada, atuando no mercado financeiro.

\section{SUMÁRIO}

Introdução - 1. Categorização jurídica do contrato de financiamento no direito financeiro - 2. Dos limites e condições para contratação: 2.1 Limite disposto na Constituição Federal; 2.2 Dos limites e condições dispostos na Lei de Responsabilidade Fiscal; 2.3 Dos limites e condições fixados pelo Senado Federal: 2.3.1 Demais restrições previstas na Lei de Responsabilidade Fiscal; 2.3.2 Limites impostos pelo Banco Central do Brasil - 3. Da atuação do Ministério da Fazenda: 3.1 Da validade do deferimento dos pedidos de verificação de limites e condições à contratação; $3.2 \mathrm{Da}$ verificação dos limites e condições diretamente por instituição financeira: 3.2.1 Da corresponsabilidade das instituições financeiras quanto à observância dos limites e condições para contratação - 4. Das garantias dos financiamentos: o caso específico do FME e FMP - 5. Das consequências jurídicas pela contratação irregular do financiamento - Conclusão - Referências. 


\section{INTRODUÇÃO}

O Brasil, de acordo com o art. $1^{\circ}$ da Constituição Federal ${ }^{1}$, é uma República Federativa formada pela união indissolúvel dos Estados, dos Municípios e do Distrito Federal, sendo a federação representada pela figura jurídica da União.

Neste cenário, é natural que existam relações jurídicas entre os membros da Federação e a União, em razão das competências estabelecidas no Título III da Constituição Federal, referente à Organização do Estado.

Sob o aspecto financeiro, a União Federal foi contemplada com uma competência tributária ampla ${ }^{2}$ se comparada com a dos Estados, dos Municípios e do Distrito Federal, possuindo um maior poderio financeiro diante das demais pessoas políticas.

Nesse contexto, os artigos 157 a 162 da Constituição Federal disciplinam a repartição das receitas tributárias, classificadas como receitas transferidas, que decorrem da transferência de recursos entre os entes da Federação, inseridas no debate do Federalismo Fiscal.

No entanto, muitas vezes as receitas tributárias originárias, derivadas e transferidas dos Estados, dos Municípios e do Distrito Federal não fazem frente às necessidades de investimentos dessas pessoas políticas.

Por este motivo, é comum que Estados, Municípios e o Distrito Federal recorram a instituições financeiras sob o controle da União Federal para obter recursos com o objetivo de realizar determinada obra ou prestar determinado serviço.

Neste contexto que se insere o debate realizado no âmbito do presente trabalho, em que serão analisados os limites legais da concessão de financiamento aos Estados, ao Distrito Federal e aos Municípios por Instituição Financeira Federal, abordando, no tópico específico relativo às garantias, a possibilidade de vinculação de receitas do Fundo de Participação dos Estados ("FPE") e do Fundo de Participação dos Municípios ("FPM").

\section{CATEGORIZAÇÃO JURÍDICA DO CONTRATO DE FINANCIAMENTO NO DIREITO FINANCEIRO}

É imprescindível ao estudo proposto enquadrar o negócio jurídico de financiamento dentre os institutos jurídicos capitulados pelo Direito Financeiro.

\footnotetext{
1 Art. $1^{\circ}$ A República Federativa do Brasil, formada pela união indissolúvel dos Estados e Municípios e do Distrito Federal, constitui-se em Estado Democrático de Direito e tem como fundamentos:

2 Citam-se os artigos 149, 153, 154 e 195 da Constituição Federal.
} 
Nessa esteira, Fábio Ulhoa Coelho assim delineia o conceito de financiamento como sendo:

(...) aquele mútuo bancário em que o mutuário assume a obrigação de conferir ao dinheiro emprestado uma determinada finalidade, como, por exemplo, investir no desenvolvimento de uma atividade econômica ou adquirir a casa própria ${ }^{3}$.

Conceituação similar é conferida pelo Banco Central do Brasil, que assim estabelece o conceito de financiamento:

Assim como o empréstimo bancário, o financiamento também é um contrato entre o cliente e a instituição financeira, mas com destinação específica dos recursos tomados, como, por exemplo, a aquisição de veículo ou de bem imóvel. Geralmente o financiamento possui algum tipo de garantia, como, por exemplo, alienação fiduciária ou hipoteca ${ }^{4}$.

Por sua vez, diante da definição de operação de crédito trazida pela Lei Complementar n. 101/2000 ("Lei de Responsabilidade Fiscal”), especificamente no art. 29 , III ${ }^{5}$, parece-nos claro que o conceito de financiamento, na seara do Direito Financeiro, pode ser enquadrado como uma operação de crédito, pois se trata de um mútuo qualificado por finalidade específica.

Categorizado o financiamento sob a ótica do Direito Financeiro, passa-se à análise dos temas que delimitam a sua concessão aos Estados, ao Distrito Federal e aos Municípios por instituições financeiras federais.

\section{DOS LIMITES E CONDIÇÕES PARA CONTRATAÇÃO}

$\mathrm{O}$ autor Regis Fernandes de Oliveira, ao discorrer sobre a contratação de operações de crédito, sob a ótica da dívida pública e dos ditames da Lei de Responsabilidade Fiscal, aduz que:

A operação de crédito pode ter diversos instrumentos. De qualquer forma, constitui-se em obrigação bilateral. $\mathrm{O}$ ato de autorização do empréstimo

3 ULHOA, Fabio Coelho. Manual de Direito Comercial. 13. ed. São Paulo: Saraiva, 2002, p. 501.

4 In: http://www.bcb.gov.br/pre/bc_atende/port/servicos9.asp. Acesso em 24/06/2018.

5 Art. 29. Para os efeitos desta Lei Complementar, são adotadas as seguintes definições: (...) III - operação de crédito: compromisso financeiro assumido em razão de mútuo, abertura de crédito, emissão e aceite de título, aquisição financiada de bens, recebimento antecipado de valores provenientes da venda a termo de bens e serviços, arrendamento mercantil e outras operações assemelhadas, inclusive com o uso de derivativos financeiros; (grifo nosso). 
pode ser unilateral, uma vez que decorre de ato típico do Estado. De outro lado, para que surja a operação, é ela contratual e necessita de vínculo bilateral. Como já esclareci, cuida-se de contrato de direito público porque a) deve haver prévia previsão orçamentária; b) exige disposição legal específica; c) há obrigatoriedade de autorização e controle do Senado; d) necessária a finalidade pública; e) é possível alteração unilateral de determinadas cláusulas, se assim for previsto na lei; f) há sujeição a prestação de contas; g) há inviabilidade de execução específica; h) pode ocorrer a rescisão unilateral ${ }^{6}$.

Trazida a exposição do doutrinador, cumpre observar que os limites e condições para contratação de financiamentos por parte de Estados, Distrito Federal e Municípios possuem quatro fontes distintas: a Constituição Federal, a Lei de Responsabilidade Fiscal, as Resoluções do Senado Federal e as Resoluções do Banco Central do Brasil.

\subsection{Limite disposto na Constituição Federal}

Como regra geral, o art. 167, inciso III da Constituição Federal ${ }^{7}$ veda a contratação de operações de crédito que excedam o montante das despesas de capital do ente contratante. $\mathrm{O}$ mesmo dispositivo, em sua segunda parte, traz exceção à regra, ou seja, permite-se a contratação de operações de crédito em excesso às despesas de capital caso elas sejam autorizadas por créditos complementares ou especiais com finalidade específica, aprovados por maioria absoluta do poder legislativo do ente contratante.

Por sua vez, os critérios para apuração do limite previsto no dispositivo constitucional em tela deverão ser calculados nos termos do art. $32, \mathbb{S} 3^{\circ}$ da Lei de Responsabilidade Fiscal ${ }^{8}$, abarcando cada ente da Federação, inclusive as empre-

6 OLIVEIRA, Regis Fernandes de. Curso de direito financeiro. 7. ed. São Paulo: Revista dos Tribunais, 2015. p. 793-794.

7 Art. 167. São vedados: (...) III - a realização de operações de créditos que excedam o montante das despesas de capital, ressalvadas as autorizadas mediante créditos suplementares ou especiais com finalidade precisa, aprovados pelo Poder Legislativo por maioria absoluta; (...).

8 Art. 32. O Ministério da Fazenda verificará o cumprimento dos limites e condições relativos à realização de operações de crédito de cada ente da Federação, inclusive das empresas por eles controladas, direta ou indiretamente. $\mathbb{S} 1^{\circ} \mathrm{O}$ ente interessado formalizará seu pleito fundamentando-o em parecer de seus órgãos técnicos e jurídicos, demonstrando a relação custo-benefício, o interesse econômico e social da operação e o atendimento das seguintes condições: (...) V - atendimento do disposto no inciso III do art. 167 da Constituição; (...) $\mathbb{3} 3^{\circ}$ Para fins do disposto no inciso $\mathrm{V}$ do $\mathbb{S} 1^{\circ}$, considerar-se-á, em cada exercício financeiro, o total dos recursos de operações de crédito nele ingressados e o das despesas de capital executadas, observado o 
sas controladas, direta ou indiretamente. Além disso, devem ser observadas as regras contidas no art. $6^{\circ}$ da Resolução n. 43/2001 do Senado Federal, que será analisada oportunamente.

\subsection{Dos limites e condições dispostos na Lei de Responsabilidade Fiscal}

Como se verá, a Lei em comento lança minuciosa regulamentação sobre a concessão de financiamento ora estudada. Ao analisar o tema, Flávio da Cruz ${ }^{9}$ atrela o comportamento do legislador ao interesse público na contratação. Confira-se:

A rígida regulamentação visa fazer com que as operações de crédito apenas se efetivem se, de fato, contribuírem para toda a coletividade, dependendo, para tanto, de estudos prévios que justifiquem, inclusive sua inserção por meio de expressa autorização para contratação, constante no orçamento do ente solicitante (...)

Feita essas considerações, passa-se à análise do assunto. O art. 32 da Lei de Responsabilidade Fiscal ${ }^{10}$ estabelece patamares legais que devem ser observados pelos entes solicitantes do financiamento.

seguinte: I - não serão computadas nas despesas de capital as realizadas sob a forma de empréstimo ou financiamento a contribuinte, com o intuito de promover incentivo fiscal, tendo por base tributo de competência do ente da Federação, se resultar a diminuição, direta ou indireta, do ônus deste; II - se o empréstimo ou financiamento a que se refere o inciso I for concedido por instituição financeira controlada pelo ente da Federação, o valor da operação será deduzido das despesas de capital; (...).

9 CRUZ, Flavio da et al (Org.). Lei de responsabilidade fiscal comentada: Lei complementar n. 101, de 4 de maio de 2000. 5. ed. São Paulo: Atlas, 2006. p. 154.

10 Art. 32. O Ministério da Fazenda verificará o cumprimento dos limites e condições relativos à realização de operações de crédito de cada ente da Federação, inclusive das empresas por eles controladas, direta ou indiretamente. $\mathbb{S} 1^{\circ} \mathrm{O}$ ente interessado formalizará seu pleito fundamentando-o em parecer de seus órgãos técnicos e jurídicos, demonstrando a relação custo-benefício, o interesse econômico e social da operação e o atendimento das seguintes condições: I existência de prévia e expressa autorização para a contratação, no texto da lei orçamentária, em créditos adicionais ou lei específica; II - inclusão no orçamento ou em créditos adicionais dos recursos provenientes da operação, exceto no caso de operações por antecipação de receita; III - observância dos limites e condições fixados pelo Senado Federal; IV - autorização específica do Senado Federal, quando se tratar de operação de crédito externo; V - atendimento do disposto no inciso III do art. 167 da Constituição; VI - observância das demais restrições estabelecidas nesta Lei Complementar. 
$\mathrm{O} \mathbb{S} 1^{\circ}$ do art. 32 estabelece como requisito para a formalização do pedido de financiamento a existência de parecer de órgãos técnicos e jurídicos do ente solicitante, demonstrando, a respeito da operação financeira, (i) a relação custo-benefício, (ii) o interesse econômico e social e (iii) o atendimento das condições cumulativas constantes nos incisos do dispositivo.

A respeito da relação custo-benefício, conforme leciona o professor José Mauricio Conti ${ }^{11}$, a obrigação de celebração de instrumentos jurídicos com a adequada relação custo-benefício já é consignada na própria Constituição Federal, em seu art. $70^{12}$. O dispositivo prevê a fiscalização das contas públicas, e, dentre outros prismas da atividade fiscalizatória, prevê o controle de economicidade dos atos do administrador público.

Em outra obra, o referido autor, ao discorrer sobre a fiscalização tendo a economicidade como referência, vaticina:

(...) a fiscalização quanto a economicidade é aquela que analisa os atos administrativos do ponto de vista econômico, no sentido de verificar se, por ocasião de sua realização, houve adequada observância da relação custo-benefício, de modo que os recursos públicos tenham sido utilizados de forma mais vantajosa e eficiente para o Poder Público ${ }^{13}$.

Logo, o Estado, Município ou o Distrito Federal, que esteja disposto a contratar um financiamento, deverá comprovar a adequação entre o montante dos recursos pretendidos e a finalidade perseguida com o negócio.

Já o requisito do interesse econômico social se revela na medida em que o financiamento é proposto para atender o interesse da coletividade. Em outras palavras, a operação deve ser celebrada objetivando atender determinado interesse específico dos administrados.

Neste ponto, cumpre salientar que, a respeito do parecer técnico e jurídico, Régis Fernandes de Oliveira assevera: "O parecer, aqui, não tem caráter vinculativo, mas é importante para evitar qualquer sanção administrativa, uma vez que

11 CONTI, José Mauricio. Arts. 32 a 39. In: MARTINS, Ives Gandra et al. (Org.). Comentários à Lei de Responsabilidade Fiscal. 5. ed. São Paulo: Saraiva, 2011. p. 273.

12 Art. 70. A fiscalização contábil, financeira, orçamentária, operacional e patrimonial da União e das entidades da administração direta e indireta, quanto à legalidade, legitimidade, economicidade, aplicação das subvenções e renúncia de receitas, será exercida pelo Congresso Nacional, mediante controle externo, e pelo sistema de controle interno de cada Poder.

13 CONTI, José Mauricio. Direito Financeiro na Constituição de 1988. São Paulo: Oliveira Mendes. p. 5. 
o Tribunal de Contas da União já decidiu que descabe pena se alguém age sob orientação." 14 .

Nessa seara, vale citar o art. 28 do Decreto-Lei n. 4.657/1942 ${ }^{15}$, que possui determinação legal de que o agente público somente responderá pessoalmente por suas decisões ou opiniões técnicas na hipótese de se configurar dolo ou erro grosseiro.

A respeito do último requisito que deve constar no parecer técnico e jurídico, qual seja, o atendimento das exigências constantes nos incisos do art. $32, \mathbb{S} 1^{\mathrm{o}} \mathrm{da}$ Lei de Responsabilidade Fiscal, verifica-se que tais dispositivos estabelecem as seguintes condições: (i) existência de prévia e expressa autorização para a contratação, no texto da lei orçamentária, em créditos adicionais ou lei específica; (ii) inclusão no orçamento ou em créditos adicionais dos recursos provenientes da operação, exceto no caso de operações por antecipação de receita; (iii) observância dos limites e condições fixados pelo Senado Federal; (iv) autorização específica do Senado Federal, quando se tratar de operação de crédito externo; (v) atendimento do disposto no inciso III do art. 167 da Constituição; e (vi) observância de demais restrições específicas contidas na Lei de Responsabilidade Fiscal.

O requisito previsto no inciso I consagra a ideia de que não pode ocorrer uma despesa pública sem que exista a correlata autorização do poder legislativo competente. Por sua vez, o inciso II indica que é necessária a inclusão no orçamento ou em créditos adicionais de recursos provenientes da operação de crédito, ou, no caso específico, do financiamento.

Dado que o disposto no inciso $\mathrm{V}$ já foi objeto de ponderações no item 2.1, quando se tratou do limite previsto na Constituição Federal, resta, portanto, tecer ponderações sobre as regras arroladas pelo Senado Federal e sobre outras restrições dispostas na Lei de Responsabilidade Fiscal, na esteira do previsto, respectivamente, no art. $32, \mathbb{S} 1^{\circ}$, incisos III e VI.

\subsection{Dos limites e condições fixados pelo Senado Federal}

A competência do Senado Federal para tratar do assunto está prevista no art. 52 , inciso VII, da Constituição Federal ${ }^{16}$. Já os limites e condições que Distrito

14 OLIVEIRA, Regis Fernandes de. Curso de direito financeiro. 7. ed. São Paulo: Revista dos Tribunais, 2015. p. 794.

15 Art. 28. O agente público responderá pessoalmente por suas decisões ou opiniões técnicas em caso de dolo ou erro grosseiro.

16 Art. 52. Compete privativamente ao Senado Federal: (...) VII - dispor sobre limites globais e condições para as operações de crédito externo e interno da União, dos Estados, do Distrito 
Federal, Estados e Municípios devem observar para contratar financiamentos estão dispostos no capítulo III da Resolução n. 43/2001 do Senado Federal ("RSF n. 43/2001").

O art. $3^{\circ}$ da RSF n. 43/2001 ${ }^{17}$ estabelece o conceito de operação de crédito, que deve ser objeto de interpretação conjunta com o art. 29, inciso III, da Lei de Responsabilidade Fiscal.

Assim, não serão analisados os artigos 10,11,12, 13, 14, 19, 20 e 36 a 42 da RSF n. 43/2001, pois tais dispositivos tratam de dívida mobiliária, de operação de crédito por antecipação de receita orçamentária e de operação de crédito externa.

Feita a necessária consideração inicial, passa-se à análise dos dispositivos pertinentes do normativo do Senado Federal. $\mathrm{O}$ artigo $5^{\circ}$ trata das vedações aos Estados, Distrito Federal e Municípios e será analisado no tópico específico referente às garantias. $\mathrm{O}$ art. $6^{018}$, já mencionado, versa sobre a necessidade de verifi-

Federal e dos Municípios, de suas autarquias e demais entidades controladas pelo Poder Público federal; (...).

17 Art. $3^{\circ}$ Constitui operação de crédito, para os efeitos desta Resolução, os compromissos assumidos com credores situados no País ou no exterior, em razão de mútuo, abertura de crédito, emissão e aceite de título, aquisição financiada de bens, recebimento antecipado de valores provenientes da venda a termo de bens e serviços, arrendamento mercantil e outras operações assemelhadas, inclusive com o uso de derivativos financeiros. $\mathbb{S} 1^{\circ}$ Equiparam-se a operações de crédito: I - recebimento antecipado de valores de empresa em que o Poder Público detenha, direta ou indiretamente, a maioria do capital social com direito a voto, salvo lucros e dividendos, na forma da legislação; II - assunção direta de compromisso, confissão de dívida ou operação assemelhada, com fornecedor de bens, mercadorias ou serviços, mediante emissão, aceite ou aval de títulos de crédito; III - assunção de obrigação, sem autorização orçamentária, com fornecedores para pagamento a posteriori de bens e serviços. $\mathbb{S} 2^{\circ}$ Não se equiparam a operações de crédito: I - assunção de obrigação entre pessoas jurídicas integrantes do mesmo Estado, Distrito Federal ou Município, nos termos da definição constante do inciso I do art. $2^{\circ}$ desta Resolução; II - parcelamento de débitos preexistentes junto a instituições não-financeiras, desde que não impliquem elevação do montante da dívida consolidada líquida.

18 Art. $6^{\circ} \mathrm{O}$ cumprimento do limite a que se refere o inciso III do art. 167 da Constituição Federal deverá ser comprovado mediante apuração das operações de crédito e das despesas de capital conforme os critérios definidos no art. 32, $\mathbb{S} 3^{\circ}$, da Lei Complementar n. 101, de 4 de maio de 2000. $\$ 1^{\circ}$ Para fins do disposto neste art. , verificar-se-ão, separadamente, o exercício anterior e o exercício corrente, tomando-se por base: I - no exercício anterior, as receitas de operações de crédito nele realizadas e as despesas de capital nele executadas; e

II - no exercício corrente, as receitas de operação de crédito e as despesas de capital constantes da lei orçamentária. $\mathbb{S} 2^{\circ}$ Não serão computados como despesas de capital, para os fins deste 
cação do cumprimento do limite de despesas de capital a que se refere o inciso III do art. 167 da Constituição Federal, cotejando-o com os critérios definidos no art. 32, $\mathbb{\int} 3^{\circ}$, da Lei de Responsabilidade Fiscal.

$\mathrm{O}$ art. $7^{\circ}$ da RSF n. 43/2001 ${ }^{19}$ traz os limites à contratação de financiamento por Estados, Municípios e pelo Distrito Federal, sob a ótica da receita do ente federado.

artigo: I - o montante referente às despesas realizadas, ou constantes da lei orçamentária, conforme o caso, em cumprimento da devolução a que se refere o art. 33 da Lei Complementar n. 101, de 2000; II - as despesas realizadas e as previstas que representem empréstimo ou financiamento a contribuinte, com o intuito de promover incentivo fiscal, tendo por base tributo de competência do ente da Federação, se resultar a diminuição, direta ou indireta, do ônus deste; e III - as despesas realizadas e as previstas que representem inversões financeiras na forma de participação acionária em empresas que não sejam controladas, direta ou indiretamente, pelos entes da Federação ou pela União. $\mathbb{S} 3^{\circ} \mathrm{O}$ empréstimo ou financiamento a que se refere o inciso II do $\mathbb{S} 2^{\circ}$, se concedido por instituição financeira controlada pelo ente da Federação, terá seu valor deduzido das despesas de capital. $\mathbb{S} 4^{\circ}$ As operações de antecipação de receitas orçamentárias não serão computadas para os fins deste artigo, desde que liquidadas no mesmo exercício em que forem contratadas. $\mathbb{S} 5^{\circ}$ Para efeito do disposto neste art., entende-se por operação de crédito realizada em um exercício o montante de liberação contratualmente previsto para o mesmo exercício. $\$ 6^{\circ}$ Nas operações de crédito com liberação prevista para mais de um exercício financeiro, o limite computado a cada ano levará em consideração apenas a parcela a ser nele liberada.

19 Art. $7^{\circ}$ As operações de crédito interno e externo dos Estados, do Distrito Federal, dos Municípios observarão, ainda, os seguintes limites: I - o montante global das operações realizadas em um exercício financeiro não poderá ser superior a $16 \%$ (dezesseis por cento) da receita corrente líquida, definida no art. $4^{\circ}$; II - o comprometimento anual com amortizações, juros e demais encargos da dívida consolidada, inclusive relativos a valores a desembolsar de operações de crédito já contratadas e a contratar, não poderá exceder a 11,5\% (onze inteiros e cinco décimos por cento) da receita corrente líquida; III - o montante da dívida consolidada não poderá exceder o teto estabelecido pelo Senado Federal, conforme o disposto pela Resolução que fixa o limite global para o montante da dívida consolidada dos Estados, do Distrito Federal e dos Municípios. $\mathbb{S} 1^{\circ} \mathrm{O}$ limite de que trata o inciso I, para o caso de operações de crédito com liberação prevista para mais de um exercício, será calculado levando em consideração o cronograma anual de ingresso, projetando-se a receita corrente líquida de acordo com os critérios estabelecidos no $\mathbb{3} 6^{\circ}$ deste artigo. $\mathbb{S} 2^{\circ} \mathrm{O}$ disposto neste art. não se aplica às operações de concessão de garantias e de antecipação de receita orçamentária, cujos limites são definidos pelos arts. $9^{\circ} \mathrm{e}$ 10 , respectivamente. $\mathbb{S} 3^{\circ}$ São excluídas dos limites de que trata o caput as seguintes modalidades de operações de crédito: I - contratadas pelos Estados e pelos Municípios com a União, organismos multilaterais de crédito ou instituições oficiais federais de crédito ou de fomento, com a finalidade de financiar projetos de investimento para a melhoria da administração das receitas e da gestão fiscal, financeira e patrimonial, no âmbito de programa proposto pelo Poder Executivo Federal; II - contratadas no âmbito do Programa Nacional de Iluminação Pública Eficiente 
Quanto aos limites, de acordo com os incisos I, II e III do art. $7^{\circ}$ da RSF $n$. 43/2001, destaca-se que os Estados, os Municípios e o Distrito Federal não podem contratar financiamento em montante global superior a $16 \%$ de sua receita corrente líquida, definida no art. $4^{\mathrm{o} 20}$ da RSF n. 43/2001. Além disso, o compro-

- Reluz, estabelecido com base na Lei n. 9.991, de 24 de julho de 2000. III - contratadas diretamente com o Banco Nacional de Desenvolvimento Econômico e Social (BNDES), ou com seus agentes financeiros credenciados, no âmbito do programa de empréstimo aos Estados e ao Distrito Federal de que trata o art. 9-N da Resolução n. 2.827, de 30 de março de 2001, do Conselho Monetário Nacional (CMN), e suas alterações. IV - destinadas ao financiamento de infraestrutura para a realização da Copa do Mundo FIFA 2014 e dos Jogos Olímpicos e Paraolímpicos de 2016, autorizadas pelo Conselho Monetário Nacional (CMN). $\$ 4^{\circ}$ Para efeitos de atendimento ao disposto no inciso II do caput, o cálculo do comprometimento anual com amortizações e encargos será feito pela média anual da relação entre o comprometimento previsto e a receita corrente líquida projetada ano a ano, considerando-se, alternativamente, o que for mais benéfico: I - todos os exercícios financeiros em que houver pagamentos previstos da operação pretendida; ou II - os exercícios financeiros em que houver pagamentos até 31 de dezembro de $2027 ; \mathbb{S} 5^{\circ}(\ldots) ; \mathbb{\$} 6^{\circ}$ Para os efeitos deste art. , a receita corrente líquida será projetada mediante a aplicação de fator de atualização a ser divulgado pelo Ministério da Fazenda, sobre a receita corrente líquida do período de 12 (doze) meses findos no mês de referência. $\mathbb{S} 7^{\circ} \mathrm{O}$ disposto neste art. não se aplica às operações de reestruturação e recomposição do principal de dívidas. $\mathbb{S}$ $8^{\circ} \mathrm{O}$ disposto no inciso II do caput não se aplica às operações de crédito que, na data da publicação desta Resolução estejam previstas nos Programas de Ajuste dos Estados, estabelecidos nos termos da Lei n. 9.496, de 11 de setembro de 1997, e, no caso dos Municípios, nos contratos de refinanciamento de suas respectivas dívidas com a União, ou aquelas que, limitadas ao montante global previsto, vierem a substituí-las. $\mathbb{S} 9^{\circ}$ Os projetos de implantação de infraestrutura de que trata o inciso IV do $\mathbb{3} 3^{\circ}$ deste art. continuarão a gozar de excepcionalidade, em relação aos limites de endividamento, até sua plena execução, ainda que excluídos da matriz de responsabilidade da Copa do Mundo Fifa 2014 e venham a ser financiados por outras fontes alternativas de financiamento, desde que a execução das obras seja iniciada até 30 de junho de 2014.

20 Art. $4^{\circ}$ Entende-se por receita corrente líquida, para os efeitos desta Resolução, o somatório das receitas tributárias, de contribuições, patrimoniais, industriais, agropecuárias, de serviços, transferências correntes e outras receitas também correntes, deduzidos: I - nos Estados, as parcelas entregues aos Municípios por determinação constitucional; II - nos Estados e nos Municípios, a contribuição dos servidores para o custeio do seu sistema de previdência e assistência social e as receitas provenientes da compensação financeira citada no $\mathbb{S} 9^{\circ}$ do art. 201 da Constituição Federal. $\mathbb{S} 1^{\circ}$ Serão computados no cálculo da receita corrente líquida os valores pagos e recebidos em decorrência da Lei Complementar n. 87, de 13 de setembro de 1996, e do Fundo previsto pelo art. 60 do Ato das Disposições Constitucionais Transitórias. $\mathbb{S} 2^{\circ}$ Não serão considerados na receita corrente líquida do Distrito Federal e dos Estados do Amapá e de Roraima os recursos recebidos da União para atendimento das despesas com pessoal, na forma dos incisos XIII e XIV do art. 21 da Constituição Federal e do art. 31 da Emenda Constitucional n. 19, de 1998. $\mathbb{S} 3^{\circ}$ A receita corrente líquida será apurada somando- se as receitas arrecadadas no mês em referên- 
metimento anual com amortizações e encargos da dívida consolidada, inclusos valores referentes às liberações de operações de crédito já contratadas ou a liberar, não podem exceder $11,5 \%$ da receita corrente líquida ${ }^{21}$. Ainda, o montante da dívida consolidada não poderá ultrapassar o teto da dívida consolidada, esta definida pelo Senado Federal na Resolução n. 40/2001.

Tendo em vista que as operações de financiamento têm por característica duração superior a 365 dias, aplica-se o disposto nos $\mathbb{S} \int^{\circ}$ e $6^{\circ}$ do art. $7^{\circ}$, que indica que o montante global das operações realizadas em um exercício financeiro, para o caso de operações de crédito com liberação prevista para mais de um exercício, será calculado levando em consideração o cronograma anual de ingresso, projetando-se a receita corrente líquida de acordo com a aplicação de fator de atualização divulgado pelo Ministério da Fazenda. Nos termos do art. $7^{\circ}$ da Portaria da Secretaria do Tesouro Nacional n. 9/201722, o fator de atualização é obtido a partir da média geométrica das taxas de crescimento real do Produto Interno Bruto ("PIB”) nacional nos últimos 08 (oito) anos.

Quanto às exceções aos limites estabelecidos nos incisos do caput do art. $7^{\circ}$, o $\mathbb{S} 3^{\circ}$ do dispositivo traz hipóteses taxativas. A primeira hipótese, prevista no inciso I do $\int 3^{\circ}$ do art. $7^{\circ}$ da RSF n. 43/2001, trata da possibilidade de os Estados, Municípios e Distrito Federal contratarem financiamentos com organismos multilaterais de crédito ou instituições oficiais federais de crédito ou de fomento, com a finalidade de financiar projetos de investimento para a melhoria da administração das receitas e da gestão fiscal, financeira e patrimonial, no âmbito de programa proposto pelo Poder Executivo Federal.

O art. 110 da Lei n. 13.473/2017 (Lei de Diretrizes Orçamentárias) estabelece, em seus incisos, o rol das agências financeiras federais oficiais de fomento, quais sejam, (i) Caixa Econômica Federal, (ii) Banco do Brasil S.A, (iii) Banco do Nordeste do Brasil S.A., (iv) Banco da Amazônia S.A., (v) Banco Nacional de Desenvolvimento Econômico e Social (“BNDES”), e (vi) Financiadora de Estudos e Projetos - FINEP.

cia e nos 11 (onze) meses anteriores excluídas as duplicidades. $\$ 4^{\circ} \mathrm{A}$ análise das propostas de operações de crédito será realizada tomando-se por base a receita corrente líquida divulgada conforme a periodicidade definida na Lei Complementar n. 101, de 4 de maio de 2000.

${ }^{21}$ Deve-se cotejar esta diretiva com o $\$ 4^{\circ}$ do art. $7^{\circ}$ da RSF n. 43/2001.

22 Art. $7^{\circ}$ Para fins de projeção da Receita Corrente Líquida - RCL, conforme disposto no $\$ 6^{\circ}$ do art. $7^{\circ}$ da Resolução do Senado Federal n. 43, de 2001, será utilizado fator de atualização calculado com base na apuração pela média geométrica das taxas de crescimento do Produto Interno Bruto nacional, divulgadas pelo Instituto Brasileiro de Geografia e Estatística - IBGE, do período correspondente aos últimos oito anos. 
Portanto, a exceção prevista inciso I do $\mathbb{S} 3^{\circ}$ do art. $7^{\circ}$ da RSF n. 43/2001 pode ser aplicada a contratação de financiamento com agência financeira federal de fomento por parte de Estado, Município ou Distrito Federal, desde que contemple a melhoria da administração das receitas e da gestão fiscal, financeira e patrimonial do ente tomador de recursos.

A título de exemplo, cita-se que o BNDES possui linha de crédito específica para a hipótese, a saber, o Programa de Modernização da Administração das Receitas e da Gestão Fiscal, Financeira e Patrimonial das Administrações Estaduais $(\mathrm{PMAE})^{23}$.

Ademais, o inciso III do $\mathbb{S} 3^{\circ}$ do art. $7^{\circ}$ da RSF n. 43/2001 prevê exceção específica à operação de empréstimo pelo BNDES aos Estados e ao Distrito Federal, de que trata o art. 9- $\mathrm{N}^{24}$ da Resolução do Conselho Monetário Nacional n. $2.827 / 2001^{25}$.

O inciso II do $\mathbb{3} 3^{\circ}$ do art. $7^{\circ}$ da RSF n. 43/2001 prevê hipótese de exceção para as operações de financiamento contratadas no âmbito do Programa Nacional de Iluminação Pública Eficiente ("Reluz"), ao passo que o inciso IV prevê hipótese de exceção que já perdeu o seu objeto para novas contratações de financiamento, pois era aplicável à realização da Copa do Mundo de 2014 a aos Jogos Olímpicos e Paraolímpicos de 2016.

Voltando aos limites e condições previstos na RSF n. 43/2001, tem-se o art. $15^{26}$, que impõe limite levando-se em conta o fim do mandato do chefe do Poder Executivo. Como regra geral, é vedada a contratação de operações de crédito nos últimos 120 (cento e vinte) dias de mandato do chefe do Poder Executivo de Estados, Municípios e do Distrito Federal.

${ }^{23}$ Disponível em: https://www.bndes.gov.br/wps/portal/site/home/financiamento/produto/bndes-finem-pmae. Acesso em 24/06/2018.

${ }^{24}$ Art. $9^{\circ}$-N. Fica autorizada a contratação de empréstimos em moeda pelos Estados e Distrito Federal, nas seguintes condições: (...)IV - Fonte de Recursos: BNDES, oriunda dos recursos do Fundo de Amparo ao Trabalhador (FAT) - Constitucional; (...)

${ }^{25}$ Consolida e redefine as regras para o contingenciamento do crédito ao setor público.

26 Art. 15. É vedada a contratação de operação de crédito nos 120 (cento e vinte) dias anteriores ao final do mandato do Chefe do Poder Executivo do Estado, do Distrito Federal ou do Município. $\mathbb{S} 1^{\circ}$ Excetuam-se da vedação a que se refere o caput deste artigo: I - o refinanciamento da dívida mobiliária; II - as operações de crédito autorizadas pelo Senado Federal ou pelo Ministério da Fazenda, em nome do Senado Federal, no âmbito desta Resolução, até 120 (cento e vinte) dias antes do final do mandato do Chefe do Poder Executivo; III - as operações de crédito destinadas ao financiamento de infraestrutura para a realização da Copa do Mundo FIFA 2014 e dos Jogos Olímpicos e Paraolímpicos de 2016, autorizadas pelo CMN. 
Esta regra é excepcionada pelo o parágrafo primeiro do dispositivo, interessando ao trabalho aquela prevista em seu inciso II, que trata da possibilidade de Estado, Município e Distrito Federal contratarem financiamentos desde que a aprovação pelo Ministério da Fazenda ou pelo Senado, para celebração do contrato, ocorra até cento e vinte dias do fim do mandato do chefe do Poder Executivo.

Vale citar, também, a limitação à contratação prevista no art. $16^{27}$ do normativo do Senado, que determina que Estados, Distrito Federal e Municípios não poderão tomar financiamentos caso estejam inadimplentes com instituições integrantes do sistema financeiro nacional, a exceção da hipótese de operação de crédito que busque regularizar débito contraído, o que foge à ideia de finalidade específica prevista para os contratos de financiamento.

Os artigos $9^{\circ}, 17,18$, e 47 versam sobre limites e vedações relacionadas a aspectos de garantia, já os artigos 21 a 35 da RSF n. 43/2001 versam sobre os aspectos formais dos pedidos para a realização de operações de crédito, incluídos aí os pedidos de financiamento, pelos Estados, Municípios e o Distrito Federal, destacando-se a competência do Ministério da Fazenda no procedimento. Por sua vez, do art. 43 ao art. 52, temos as disposições finais da RSF n. 43/2001.

\subsubsection{Demais restrições previstas na Lei de Responsabilidade Fiscal}

No que tange ao tema analisado neste trabalho, há uma restrição a ser destacada, prevista no art. $35, \mathbb{S} 1^{\circ 28}$. Nos termos deste dispositivo, Estados, Distrito Federal e Municípios ficam proibidos de formalizar financiamentos com instituições financeiras federais para financiar despesas correntes ou refinanciar dívidas não contraídas com a mesma instituição.

27 Art. 16. É vedada a contratação de operação de crédito por tomador que esteja inadimplente com instituições integrantes do sistema financeiro nacional, exceto quando a operação de crédito se vincular à regularização do débito contraído junto à própria instituição concedente. Parágrafo único. Para efeito da análise de que trata o caput deste art. , a verificação da adimplência será efetuada pelo número de registro no Cadastro Nacional da Pessoa Jurídica (CNPJ) que represente a pessoa jurídica do mutuário ou tomador da operação de crédito.

28 Art. 35. É vedada a realização de operação de crédito entre um ente da Federação, diretamente ou por intermédio de fundo, autarquia, fundação ou empresa estatal dependente, e outro, inclusive suas entidades da administração indireta, ainda que sob a forma de novação, refinanciamento ou postergação de dívida contraída anteriormente. $\mathbb{S} 1^{\circ}$ Excetuam-se da vedação a que se refere o caput as operações entre instituição financeira estatal e outro ente da Federação, inclusive suas entidades da administração indireta, que não se destinem a: I - financiar, direta ou indiretamente, despesas correntes; II - refinanciar dívidas não contraídas junto à própria instituição concedente. 


\subsubsection{Limites impostos pelo Banco Central do Brasil}

O Banco Central do Brasil, através da Resolução n. 4.589/2017 ("Resolução BACEN n. 4.589/2017"), define o limite de exposição e o limite global anual de crédito aos órgãos e entidades do setor público, sendo que tais limites devem ser, obrigatoriamente, respeitados por instituições financeiras e demais instituições autorizadas a funcionar pelo Banco Central do Brasil.

Nos termos do art. $1^{029}$ da Resolução BACEN n. 4.589/2017, o limite de exposição de instituição financeira com entes públicos é de $45 \%$ de seu patrimônio de referência. Interessante notar que, nos termos do parágrafo $2^{\circ}$ do art. $1^{\circ}$, não se sujeitam ao citado limite as operações financeiras que possuam garantia formal e integral da União.

Outro ponto de destaque é que as instituições financeiras podem destacar parcela do patrimônio de referência para aplicação exclusiva em operações de crédito com o setor público. Esta parcela será deduzida do patrimônio de referên-

29 Art. $1^{\circ}$ Fica limitado o montante das operações de crédito de cada instituição financeira e demais instituições autorizadas a funcionar pelo Banco Central do Brasil com órgãos e entidades do setor público a $45 \%$ (quarenta e cinco por cento) do Patrimônio de Referência (PR), nos termos da regulamentação em vigor. $\mathbb{S} 1^{\circ}$ Para efeito do disposto nesta Resolução entende-se: I - por órgãos e entidades do setor público: a) a administração direta da União, dos estados, do Distrito Federal e dos municípios; b) as autarquias e fundações instituídas ou mantidas, direta ou indiretamente, pela União, pelos estados, pelo Distrito Federal e pelos municípios; c) as empresas públicas e sociedades de economia mista não financeiras, suas subsidiárias e demais empresas controladas, direta ou indiretamente, pela União, pelos estados, pelo Distrito Federal e pelos municípios, inclusive as sociedades de objeto exclusivo; e d) os demais órgãos ou entidades dos poderes da União, dos estados, do Distrito Federal e dos municípios; II - por operação de crédito: a) os empréstimos e financiamentos; b) as operações de arrendamento mercantil; c) a aquisição definitiva ou realizada por meio de operações compromissadas de revenda de títulos e valores mobiliários de emissão dos órgãos e entidades do setor público mencionados no inciso I, alínea "c", deste parágrafo, exclusive a aquisição definitiva de ações de sociedades de economia mista; d) a concessão de garantias de qualquer natureza; e Resolução n. 4.589, de 29 de junho de 2017 Página 2 de 6 e) toda e qualquer operação que resulte, direta ou indiretamente, em concessão de crédito e/ou captação de recursos de qualquer natureza, inclusive com uso de derivativos financeiros. $\mathbb{S} 2^{\circ}$ Não estão sujeitas ao limite estabelecido no caput as operações de crédito de responsabilidade ou que tenham garantia formal e integral da União. $\mathbb{S} 3^{\circ}$ As instituições financeiras e demais instituições autorizadas a funcionar pelo Banco Central do Brasil sujeitas à elaboração de Demonstrações Contábeis consolidadas do Conglomerado Prudencial, nos termos da Resolução n. 4.280, de 31 de outubro de 2013, devem apurar o limite de que trata o caput de forma consolidada. 
cia para efeito do cálculo do limite de $45 \%$ de exposição. Esta regra está estabelecida no art. $2^{\circ}$ da Resolução BACEN n. 4.589/2017³.

$\mathrm{O}$ art. $4^{\circ}$ da Resolução BACEN n. 4.589/2017 elenca diversos requisitos formais às contratações de operações por instituição financeiras e demais instituições autorizadas a funcionar pelo Banco Central do Brasil. Além disso, o art. $5^{031}$ estabelece que o limite global para novas operações de crédito será estabelecido anualmente, em seu anexo único. Para o ano de 2018, o limite para operações com garantia da União é de sete bilhões de reais. Por sua vez, para operações sem garantia da União, o limite é de dezessete bilhões.

\section{DA ATUAÇÃO DO MINISTÉRIO DA FAZENDA}

Consoante ao já citado art. 32 da Lei de Responsabilidade Fiscal, cabe ao Ministério da Fazenda verificar o cumprimento dos limites e condições à formalização de financiamentos envolvendo Estados, Distrito Federal e Municípios.

Antes de adentrar propriamente o assunto, cabe consignar crítica feita por Kiyoshi Harada ${ }^{32}$ à função dispensada ao Ministério da Fazenda pelo legislador infraconstitucional. $\mathrm{O}$ autor defende que a atribuição conferida ao Ministério da Fazenda não possui matriz constitucional, ferindo o art. $1^{\circ}$, o art. 18 e o art. 24 ,

30 Art. $2^{\circ}$ As instituições financeiras e demais instituições autorizadas a funcionar pelo Banco Central do Brasil podem destacar parcela do PR para aplicação exclusiva em operações de crédito com órgãos e entidades do setor público, que será deduzida do PR para efeito do cálculo de todos os limites operacionais, inclusive daquele previsto no art. $1^{\circ}$ desta Resolução.

31 Art. $5^{\circ} \mathrm{O}$ limite global anual das novas operações de crédito contratadas pelas instituições financeiras e demais instituições autorizadas a funcionar pelo Banco Central do Brasil com órgãos e entidades do setor público será definido para cada exercício em Anexo a esta Resolução. $\mathbb{S} 1^{\circ}$ Para efeito do disposto no caput, o Conselho Monetário Nacional estabelecerá, até o final de cada exercício, o limite vigente para o exercício seguinte, especificando os montantes máximos que poderão ser contratados em operações de crédito com e sem garantia da União. $\$ 2^{\circ}$ Não se incluem no valor global estabelecido conforme o disposto no caput as seguintes operações de crédito das instituições financeiras e demais instituições autorizadas a funcionar pelo Banco Central do Brasil: I - contratadas com as entidades mencionadas na alínea "c" do inciso I do $\ 1^{\circ}$ do art. $1^{\circ}$ desta Resolução relativamente às operações de amparo à exportação; II - operações descritas na alínea "c" do inciso II do $\mathbb{S} 1^{\circ}$ do art. $1^{\circ}$ desta Resolução; e III - operações de crédito realizadas pelas Agências de Fomento e pelos Bancos de Desenvolvimento, desde que realizadas com destaque de parcela do PR, na forma do art. $2^{\circ}$ desta Resolução.

32 HARADA, Kiyoshi. Responsabilidade fiscal: Lei Complementar n 101/2000 comentada e legislação correlata anotada. São Paulo: Juarez de Oliveira, 2002. p. 156. 
$\mathbb{S} 1^{\circ}$ da Carta Constitucional, em razão da usurpação da competência constitucional do Senado Federal, in verbis:

A atribuição conferida ao Ministério da Fazenda não tem matriz constitucional. O Ministério da Fazenda passa a exercer um controle interno sui generis, que extrapola do âmbito da Administração Federal. Passa a desempenhar um papel de superórgão nacional, destinado a exercer o controle externo, invadindo esferas próprias dos Legislativos estaduais e municipais e de seus respectivos Tribunais de Contas. Tal faculdade outorgada ao Ministério da Fazenda, agride os arts. $1^{\circ}$ e 18 da CF. Fere também o art. 24, $\mathbb{S}$ $1^{\circ}$, da CF, pois no campo de legislação concorrente compete à União apenas estabelecer normas gerais. Cabe à Casa Legislativa de cada entidade política examinar o requisito do indispensável interesse público na contratação de operações creditícias, dentro dos limites e condições fixados pelo Senado Federal. Usurpa pois, a competência privativa do Senado Federal, órgão legislativo equidistante dos entes componentes da Federação, que tem a missão de dispor sobre limites globais e condições para as operações de crédito interno e externo, nos termos do art. 52, VII da CF (...).

Não obstante a robustez dos fundamentos alinhavados, trata-se de posicionamento isolado e, com todo o respeito e apreço ao jurista Kiyoshi Harada, não acompanhado pelo presente trabalho.

Aos nossos olhos, a atuação do Ministério da Fazenda não viola as mencionadas disposições constitucionais, muito menos usurpa competência do Senado Federal. A função do órgão federal é verificar os limites e condições impostas pelo Senado, sem a criação de novos obstáculos à contratação do financiamento. A função do Ministério da Fazenda é meramente executiva, não havendo espaço para criação e regulamentação diversa daquela elaborada pelo Senado Federal.

Igualmente, não se ocupa indevidamente a função de casa legislativa na mensuração do interesse público subjacente à celebração de financiamentos. Este papel é feito pelo Poder Legislativo competente, ao aprovar na lei orçamentária o crédito adicional ou lei específica que preveja a contratação do negócio jurídico. Frisa-se que, como já visto anteriormente, esta é, inclusive, uma condição para celebração do contrato de financiamento. Repisa-se que o papel do Ministério da Fazenda é executório, cabendo-lhe atestar a existência e a conformidade de requisitos estabelecidos pelas instâncias competentes.

Feita essa consideração, passa-se à análise da atuação do Ministério da Fazenda. Através da Secretaria do Tesouro Nacional ("STN"), foi emitido o Manual para Instrução de Pleitos ("MIP") 33. Este manual estabelece, por tipo de

33 Disponível em: https://conteudo.tesouro.gov.br/manuais/mip/63-1-apresentacao/9-1-1-o-manual-para-instrucao-de-pleitos-mip. Acesso em 14/06/2018. 
operação de crédito e concessão de garantia, o fluxo procedimental para contratação, as condições ou vedações aplicáveis, os limites de endividamento a que estão submetidos os entes federados, bem como os documentos exigidos pelo Senado Federal e a sua forma de apresentação. A documentação exigida pelo Manual deriva, logicamente, da RSF n. 43/2001 e, no que importa ao presente trabalho, destacamos os incisos do art. $21^{34}$ do normativo do Senado Federal.

34 Art. 21. Os Estados, o Distrito Federal e os Municípios encaminharão ao Ministério da Fazenda os pedidos de verificação de limites e condições para a realização das operações de crédito de que trata esta Resolução, com a proposta do financiamento ou empréstimo e instruídos com: I - pedido do chefe do Poder Executivo, acompanhado de pareceres técnicos e jurídicos, demonstrando a relação custo-benefício, o interesse econômico e social da operação e o cumprimento dos limites e condições estabelecidos por esta Resolução; II - autorização legislativa para a realização da operação; III - declaração do Chefe do Poder Executivo, na forma exigida pelo Ministério da Fazenda, atestando a inclusão no orçamento vigente dos recursos provenientes da operação pleiteada, exceto no caso de operações por antecipação de receita orçamentária, ou, no caso em que o primeiro desembolso não se realize no ano da análise, declaração de inclusão no Projeto de Lei Orçamentária Anual (PLOA) do exercício subsequente, e desde que a autorização legislativa de que trata o inciso II tenha sido efetivada por meio de lei específica; IV certidão expedida pelo Tribunal de Contas competente atestando: a) em relação às contas do último exercício analisado, o cumprimento do disposto no $\mathbb{S} 2^{\circ}$ do art. 12; no art. 23; no art. 33; no art. 37; no art. 52; no $\mathbb{2} 2^{\circ}$ do art. 55; e no art. 70, todos da Lei Complementar n. 101, de 2000;b) em relação às contas dos exercícios ainda não analisados, e, quando pertinente, do exercício em curso, o cumprimento das exigências estabelecidas no $\mathbb{S} 2^{\circ}$ do art.12; no art. 23; no art. 52; no $\mathbb{S} 2^{\circ}$ do art. 55; e no art. 70, todos da Lei Complementar n. 101, de 2000, de acordo com as informações constantes nos relatórios resumidos da execução orçamentária e nos de gestão fiscal; c) a certidão deverá ser acompanhada de declaração do chefe do Poder Executivo de que as contas ainda não analisadas estão em conformidade com o disposto na alínea a; V - declaração do chefe do Poder Executivo atestando o atendimento do inciso III do art. $5^{\circ}$; VI - comprovação da Secretaria do Tesouro Nacional quanto ao adimplemento com a União relativo aos financiamentos e refinanciamentos por ela concedidos, bem como às garantias a operações de crédito, que tenham sido, eventualmente, honradas; VII - no caso específico de operações de Municípios com garantia de Estados, certidão emitida pela Secretaria responsável pela administração financeira do garantidor, que ateste a adimplência do tomador do crédito perante o Estado e as entidades por ele controladas, bem como a inexistência de débito decorrente de garantia a operação de crédito que tenha sido, eventualmente, honrada; VIII certidões que atestem a regularidade junto ao Programa de Integração Social (PIS), ao Programa de Formação do Patrimônio do Servidor Público (Pasep), ao Fundo de Investimento Social (Finsocial), à Contribuição Social para o Financiamento da Seguridade Social (Cofins), ao Instituto Nacional do Seguro Social (INSS) e ao Fundo de Garantia do Tempo de Serviço (FGTS) e, quando couber, na forma regulamentada pelo Ministério da Previdência e Assistência Social, o cumprimento da Lei n. 9.717, de 27 de novembro de 1998; IX - cronogramas de dispêndio 
Além disso, a Secretaria do Tesouro Nacional é responsável pelo Sistema de Análise da Dívida Pública ("SADIPEM") 35 . O sistema, disponível em meio eletrônico, possibilita o envio de documentação referente aos pleitos de operação de crédito dos Estados, dos Municípios e do Distrito Federal para análise da referida Secretaria.

A ferramenta objetiva: (i) aumentar a comunicação entre as partes envolvidas no processo; (ii) propiciar agilidade, transparência e controle no envio à Secretaria do Tesouro Nacional e na análise de operações de crédito e de garantias da União; (iii) dar clareza à análise apontando de maneira célere as falhas documentais que, por ventura, possam ocorrer no momento do preenchimento; e (iv) automatizar rotinas com confiabilidade tecnológica.

Verificamos, então, que o MIP e SADIPEM se complementam, pois o primeiro consolida os procedimentos para contratação, as condições ou vedações aplicáveis e os limites de endividamento referentes às operações de crédito a serem contratadas por Estados, Distrito Federal e Municípios, ao passo que o segundo é a plataforma utilizada para enviar a documentação que formaliza o pleito à Secretaria do Tesouro Nacional para análise.

\subsection{Da validade do deferimento dos pedidos de verificação de limites e condições à contratação}

Neste tópico será analisado o prazo pelo qual o deferimento do pedido de averiguação dos limites e condições feitas pelo Ministério da Fazenda se mantém válido, ou seja, qual o prazo em que o financiamento pode ser celebrado regularmente.

com as dívidas interna e externa e com a operação a ser realizada; $\mathrm{X}$ - relação de todas as dívidas, com seus valores atualizados, inclusive daqueles vencidos e não pagos, assinada pelo chefe do Poder Executivo e pelo Secretário de Governo responsável pela administração financeira; XI - Relatórios Resumidos da Execução Orçamentária (RREO), assinados pelo Chefe do Poder Executivo e pelo Secretário de Governo responsável pela administração financeira, para fins de cálculo dos limites de que trata esta Resolução; XII - comprovação do encaminhamento das contas ao Poder Executivo da União, para fins da consolidação de que trata o caput do art. 51 da Lei Complementar n. 101, de 2000; XIII - comprovação das publicações a que se referem os arts. 52 e 55, $\mathbb{S} 2^{\circ}$, da Lei Complementar n. 101, de 2000; XIV - lei orçamentária do exercício em curso; e XIV- Quadro demonstrativo da Receita e Despesa, segundo as Categorias Econômicas, integrante da lei de orçamento do exercício em curso, conforme inciso II do $\mathbb{S} 1^{\circ}$ do art. $2^{\circ}$ da Lei n. 4.320, de 17 de março de 1964, para fins de apuração do limite de que trata o art. $6^{\circ}$; XV - cronograma estimativo de liberações das operações de crédito contratadas e a contratar; XVI - cronograma estimativo de desembolso e reembolso da operação a ser contratada.

${ }_{35}$ Disponível em: https://sadipem.tesouro.gov.br/sadipem/. Acesso em 24/06/2018. 
As balizas são estabelecidas na RSF n. 43/2001, que estabelece (i) no mínimo, 180 (cento e oitenta) dias e, no máximo, 540 (quinhentos e quarenta) dias, para as operações de dívidas fundadas em operações externas, e (ii) no mínimo 90 (noventa) dias e, no máximo, 270 (duzentos e setenta) dias, para as demais operações de crédito $^{36}$. Portanto, para fins deste trabalho, consideram-se os últimos prazos.

Em complemento à regra acima exposta, a Portaria STN nº 09/2017 estabelece três faixas temporais compreendidas entre os prazos máximo e mínimo estabelecidos pelo Senado Federal. Destarte, nos termos do art. $5^{\circ}$ da Portaria STN n. 09/201737, os prazos de validade da averiguação dos limites feito pela Secretária da Fazenda Nacional podem ser de 90 (noventa), 180 (cento e oitenta) e 270 (duzentos e setenta) dias.

A definição do prazo aplicável dependerá, em regra, do percentual de comprometimento do cálculo a que se referem os incisos I, II e III do art. $7^{\circ}$ da RSF n. 43/2001. Caso o percentual seja superior a 90\%, o prazo será de 90 (noventa dias); caso o percentual seja entre $80 \%$ e $90 \%$, o prazo será de 180 (cento e oitenta dias); e caso o percentual seja inferior a $80 \%$, o prazo será de 270 (duzentos e setenta dias).

36 Art. 44. As resoluções do Senado Federal que autorizarem as operações de crédito objeto desta Resolução, bem como a verificação dos limites e condições previstos no art. 32 da Lei Complementar n. 101, de 4 de maio de 2000, incluirão, ao menos, as seguintes informações: (...) IV prazo para o exercício da autorização, que será de, no mínimo, 180 (cento e oitenta) dias e, no máximo, 540 (quinhentos e quarenta) dias para as operações de dívidas fundadas externas, e de, no mínimo, 90 (noventa) dias e, no máximo, 270 (duzentos e setenta) dias, para as demais operações de crédito.

37 Art. $5^{\circ} \mathrm{O}$ deferimento dos Pedidos de Verificação de Limites e Condições, referentes ao art. 32 da Lei Complementar n. 101, de 2000, terá, no que se refere aos limites de endividamento previstos nos incisos I, II e III do art. $7^{\circ}$ da Resolução do Senado Federal n. 43, de 2001, os seguintes prazos de validade: I - 90 (noventa) dias: se o cálculo de qualquer dos limites a que se referem os incisos I, II e III do art. $7^{\circ}$ da Resolução do Senado Federal n. 43, de 2001, resultar em percentual de comprometimento acima de 90\%; II - 180 (cento e oitenta) dias: se no cálculo a que se referem os incisos I, II e III do art. $7^{\circ}$ da Resolução do Senado Federal n. 43, de 2001, o maior limite apurado resultar em percentual de comprometimento entre $80 \%$ e $90 \%$;III - 270 (duzentos e setenta) dias: se todos os limites a que se referem os incisos I, II e III do art. $7^{\circ}$ da Resolução do Senado Federal n. 43, de 2001, resultarem em percentual de comprometimento inferior a $80 \%$. Parágrafo único. O deferimento dos Pedidos de Verificação de Limites e Condições, referentes ao art. 32 da Lei Complementar n. 101, de 2000, terá, no que se refere à excepcionalização aos limites de endividamento previstos nos inicios I, II e III do art. $7^{\circ}$ da Resolução do Senado Federal n. 43, de 2001, prazo de validade de 270 (duzentos e setenta) dias. 
Já o deferimento de pedidos de verificação de limites e condições de financiamentos que são excepcionados dos limites estabelecidos nos incisos do art. $7^{\circ}$ da RSF n. 43/2001, tem prazo de validade de 270 (duzentos e setenta dias).

Verifica-se, então, que a Portaria STN n. 09/2017 não usurpa a competência do Senado Federal ao disciplinar os prazos de forma específica, mas tão somente, como normativo juridicamente inferior à RSF n. 43/2001, detalha a aplicabilidade dos prazos a cada situação jurídico-econômica da entidade solicitante, sem extrapolar as regras legais previstas no ato juridicamente superior.

\subsection{Da verificação dos limites e condições diretamente por instituição financeira}

Por meio do art. $10^{38}$ da Lei Complementar n. 148/2014, criou-se exceção à regra de que a averiguação dos limites e condições para realização de operações de crédito deve ser realizada pelo Ministério da Fazenda. O dispositivo prevê que as próprias instituições financeiras poderão avaliar se os limites e condições do art. 32 da RSF n 43/2001 estão cumpridos, de acordo com as diretrizes estabelecidas em normativo do Ministério da Fazenda.

Apesar de a Lei Complementar n. 148/2014 ter sido publicada em 26 de novembro de 2014, o Ministério da Fazenda apenas regulamentou o comando insculpido em seu art. 10 em 04 de novembro de 2016, através da Portaria n. 413/2016 ("Portaria MF n. 413/2016"). Salienta-se que o ato normativo apenas entrou em vigor após noventa dias de sua publicação $0^{39}$, ou seja, em fevereiro do ano de 2017.

Dentre as disposições da Portaria MF n. 413/2016, destaca-se, de acordo com o art. $1^{040}$, que a averiguação direta poderá ser feita diretamente quando: (i) o valor da operação de crédito não for superior a cinco milhões de reais, e (ii) a

38 Art. 10. O Ministério da Fazenda, mediante ato normativo, estabelecerá critérios para a verificação prevista no art. 32 da Lei Complementar n. 101, de 4 de maio de 2000, diretamente pelas instituições financeiras de que trata o art. 33 da citada Lei Complementar, levando em consideração o valor da operação de crédito e a situação econômico-financeira do ente da Federação, de maneira a atender aos princípios da eficiência e da economicidade.

39 Art. $6^{\circ}$ Esta Portaria entra em vigor 90 (noventa) dias após a data de sua publicação.

40 Art. $1^{\circ}$ Estabelecer os seguintes critérios para que a verificação de limites e condições prevista no art. 32 da Lei Complementar n. 101, de 4 de maio de 2000, possa ser feita diretamente pelas instituições financeiras, conforme o art. 10 da Lei Complementar n. 148, de 25 de novembro de 2014: I - o valor da operação de crédito analisada deve ser igual ou inferior a R \$ 5.000.000,00 (cinco milhões de reais); e II - a relação entre o valor da Dívida Consolidada (DC) e a Receita Corrente Líquida (RCL) do ente federado não poderá ser superior a 1,00 (um). 
relação entre o valor da Dívida Consolidada e a Receita Corrente Líquida do ente federado não for superior a um.

Além disso, a verificação dos limites e condições não poderá ocorrer nos casos de operações internas com garantia da União, operações externas, operações de regularização de dívida e operações que possuam a mesma finalidade de outras operações já contratadas pelo ente federado (se a soma dos seus valores ultrapassar o limite de cinco milhões de reais), nos termos dos incisos do art. $2^{\circ}$ da Portaria MF n. 413/2016 ${ }^{41}$.

$\mathrm{O}$ art. $3^{\circ}$ e o art. $4^{042}$ estabelecem obrigações acessórias de prestação de informações das instituições financeiras concedentes ao Ministério da Fazenda, e o art. $5^{\text {o43 }}$ aponta que o descumprimento às regras impostas torna a operação de crédito irregular, sem prejuízo de outras penalidades aplicáveis.

\subsubsection{Da corresponsabilidade das instituições financeiras quanto à observância dos limites e condições para contratação}

Quanto ao financiamento ora analisado, o art. $33^{44}$ da Lei de Responsabilidade Fiscal institui obrigação da instituição financeira que contratar tal negócio

${ }^{41}$ Art. $2^{\circ}$ Não poderá ser realizada diretamente pelas instituições financeiras a verificação de limites e condições de: I - operações de crédito internas com garantia da União ou externas, nos termos do art. 23 da Resolução n. 43, do Senado Federal, de 2001; II - operações de regularização de dívidas, nos termos do $\mathbb{S} 5^{\circ}$ do art. 24 da Resolução n. 43, do Senado Federal, de 2001; e III - operações de crédito que possuam a mesma finalidade de outras operações já contratadas pelo ente federado se a soma dos seus valores ultrapassar o limite estabelecido no inciso I do art. $1^{\circ}$ desta Portaria.

42 Art. $3^{\circ}$ Deverão ser remetidos à Secretaria do Tesouro Nacional (STN) os pleitos que não atenderem aos arts. $1^{\circ}$ e $2^{\circ}$ desta Portaria para que proceda à verificação de limites e condições, nos termos do art. 32 da Lei Complementar n. 101, de 4 de maio de 2000, e da Resolução do Senado Federal n. 43, de 2001. Art. $4^{\circ} \mathrm{A}$ instituição financeira que realizar a verificação de limites e condições nos termos do art. $1^{\circ}$ desta Portaria deverá: I - informar ao Ministério da Fazenda, por meio do Sistema de Análise da Dívida Pública, Operações de Crédito e Garantias da União, Estados e Municípios (SADIPEM): a) o início da análise de verificação de limites e condições, no dia em que esta acontecer; e b) a contratação da operação de crédito, na data em que esta ocorrer. II - armazenar e fornecer, em até 15 dias, os documentos e informações referentes à operação de crédito e à verificação de limites e condições prevista no art. $1^{\circ}$ desta Portaria, quando solicitadas pelo Ministério da Fazenda no período de até cinco anos a contar do prazo final da referida operação.

43 Art. $5^{\circ} \mathrm{O}$ não cumprimento do previsto nesta Portaria tornará a operação de crédito irregular, sem prejuízo de outras penalidades previstas na legislação aplicável.

${ }^{44}$ Art. 33. A instituição financeira que contratar operação de crédito com ente da Federação, exceto quando relativa à dívida mobiliária ou à externa, deverá exigir comprovação de que a 
jurídico com ente da federação de exigir a comprovação de que a operação atende aos limites e condições estabelecidos. Nas palavras de Kiyoshi Harada: "O legislador cometeu às instituições financeiras a corresponsabilidade pela comprovação de que a operação de creditícia, pretendida pelo ente político, atende as condições e limites estabelecidos pelo Senado federal (...)" ${ }^{m 5}$.

\section{DAS GARANTIAS DOS FINANCIAMENTOS: O CASO ESPECÍFICO DO FME E FMP}

No que se refere à garantia do financiamento concedido por instituição financeira federal, observamos que há previsões na Constituição Federal, na Lei de Responsabilidade Fiscal e na RSF n. 43/2001.

No âmbito constitucional, verificamos que o art. 167, inciso IV $^{46}$ e o seu parágrafo quarto versam sobre a questão das garantias, vedando, em regra geral, aos Estados, aos Municípios e ao Distrito Federal a vinculação de receita de impostos a órgão, fundo ou despesa, mas, dentre as exceções elencadas no dispositivo constitucional, destaca-se a possibilidade de vinculação (i) de receitas próprias geradas pelos impostos e (ii) dos recursos de que tratam os artigos 157, 158

operação atende às condições e limites estabelecidos. $\mathbb{S} 1^{\circ} \mathrm{A}$ operação realizada com infração do disposto nesta Lei Complementar será considerada nula, procedendo-se ao seu cancelamento, mediante a devolução do principal, vedados o pagamento de juros e demais encargos financeiros. $\$ 2^{\circ}$ Se a devolução não for efetuada no exercício de ingresso dos recursos, será consignada reserva específica na lei orçamentária para o exercício seguinte. $\mathbb{S} 3^{\circ}$ Enquanto não efetuado o cancelamento, a amortização, ou constituída a reserva, aplicam-se as sanções previstas nos incisos do $\mathbb{3} 3^{\circ}$ do art. 23. $\mathbb{S} 4^{\circ}$ Também se constituirá reserva, no montante equivalente ao excesso, se não atendido o disposto no inciso III do art. 167 da Constituição, consideradas as disposições do $\mathbb{3} 3$ o do art. 32 .

${ }^{45}$ HARADA, Kiyoshi. Responsabilidade fiscal: Lei Complementar n 101/2000 comentada e legislação correlata anotada. São Paulo: Juarez de Oliveira, 2002. p. 160.

${ }^{46}$ Art. 167. São vedados: (...) IV - a vinculação de receita de impostos a órgão, fundo ou despesa, ressalvadas a repartição do produto da arrecadação dos impostos a que se referem os arts. 158 e 159, a destinação de recursos para as ações e serviços públicos de saúde, para manutenção e desenvolvimento do ensino e para realização de atividades da administração tributária, como determinado, respectivamente, pelos arts. 198, $\mathbb{S} 2^{\circ}, 212$ e 37, XXII, e a prestação de garantias às operações de crédito por antecipação de receita, previstas no art. $165, \mathbb{S} 8^{\circ}$, bem como o disposto no $\mathbb{S} 4^{\circ}$ deste artigo; (...) $\mathbb{S} 4 .^{\circ}$ É permitida a vinculação de receitas próprias geradas pelos impostos a que se referem os arts. 155 e 156, e dos recursos de que tratam os arts. 157, 158 e 159, I, a e b, e II, para a prestação de garantia ou contragarantia à União e para pagamento de débitos para com esta. 
e 159, inciso I, alíneas “a” e "b", e inciso II, para a prestação de garantia ou contragarantia à União e para pagamento de débitos para com esta.

$\mathrm{O}$ art. 159, inciso I, alíneas “a” e "b”, disciplina, respectivamente, o FPE e o FPM. A respeito do conceito de Fundo de Participação, Aliomar Baleeiro assim o define:

No Sistema Tributário Brasileiro, introduziu-se a participação de uma pessoa de Direito Público Interno no produto da arrecadação de imposto de competência de outra. Esta decreta e arrecada um imposto de distribui tantos por cento da receita respectiva entre as várias pessoas de Direito Público que a compõe $e^{47}$.

Destaca-se, sob o ponto de vista de competência tributária e de natureza financeira da receita, que os recursos do FPE e do FPM não são receitas originárias, mas sim receitas transferidas, de acordo com a definição trazida por Tathiane Piscitelli:

(...) temos as receitas transferidas, que decorrem da transferência de recursos entre os entes da Federação. Portanto, diferentemente do que ocorre com as receitas originárias e derivadas, esses recursos decorrem não de uma relação que se estabelece entre Estado e particulares, mas sim em virtude de relações entre os entes da Federação ${ }^{48}$.

Neste sentido, Luís Eduardo Schoueri ${ }^{49}$ assevera a diferença entre a competência tributária, prevista no caput do art. $7^{\circ}$ do Código Tributário Nacional $^{50} \mathrm{e}$ indelegável, e a capacidade tributária ativa, prevista no $\mathbb{S} 3^{\circ}$ do art. $7^{\circ}$ do Código Tributário Nacional e delegável.

$\mathrm{Na}$ seara da Lei de Responsabilidade Fiscal, o art. $40^{51}$ disciplina o tópico das garantias, sendo relevante destacar o disposto no inciso II do parágrafo pri-

47 BALEEIRO, Aliomar. Direito Tributário Brasileiro. Rio de Janeiro: Forense, 2008. p. 69

48 PISCITELLI, Tathiane. Direito Financeiro Esquematizado. 3. ed. São Paulo: Método, 2012. p. 83.

49 SCHOUERI, Luís Eduardo. Direito Tributário. São Paulo: Saraiva, 2011. p. 237.

${ }^{50}$ Art. $7^{\circ}$ A competência tributária é indelegável, salvo atribuição das funções de arrecadar ou fiscalizar tributos, ou de executar leis, serviços, atos ou decisões administrativas em matéria tributária, conferida por uma pessoa jurídica de direito público a outra, nos termos do $\mathbb{3} 3^{\circ}$ do artigo 18 da Constituição. $\mathbb{S} 1^{\circ} \mathrm{A}$ atribuição compreende as garantias e os privilégios processuais que competem à pessoa jurídica de direito público que a conferir. $\mathbb{\$} 2^{\circ} \mathrm{A}$ atribuição pode ser revogada, a qualquer tempo, por ato unilateral da pessoa jurídica de direito público que a tenha conferido. $\mathbb{S} 3^{\circ}$ Não constitui delegação de competência o cometimento, a pessoas de direito privado, do encargo ou da função de arrecadar tributos.

51 Art. 40. Os entes poderão conceder garantia em operações de crédito internas ou externas, observados o disposto neste artigo, as normas do art. 32 e, no caso da União, também os limites 
meiro, que determina que o oferecimento de garantias pelos Estados, os Municípios e o Distrito Federal estará condicionado ao oferecimento de contragarantia, em valor igual ou superior ao da garantia a ser concedida, sendo que a contragarantia exigida pela União a ente federado poderá consistir na vinculação de receitas tributárias (i) diretamente arrecadadas e (ii) provenientes de transferências constitucionais, com outorga de poderes ao garantidor para retê-las e empregar o respectivo valor na liquidação da dívida vencida.

Por sua vez, atinente à RSF n. 43/2001, damos evidência (i) ao art. $5^{\circ}$, inciso VI e $\mathbb{S} 4^{052}$, que trata da possibilidade de vinculação de receitas, (ii) ao

e as condições estabelecidos pelo Senado Federal. $\mathbb{S} 1^{\circ}$ A garantia estará condicionada ao oferecimento de contragarantia, em valor igual ou superior ao da garantia a ser concedida, e à adimplência da entidade que a pleitear relativamente a suas obrigações junto ao garantidor e às entidades por este controladas, observado o seguinte: I - não será exigida contragarantia de órgãos e entidades do próprio ente; II - a contragarantia exigida pela União a Estado ou Município, ou pelos Estados aos Municípios, poderá consistir na vinculação de receitas tributárias diretamente arrecadadas e provenientes de transferências constitucionais, com outorga de poderes ao garantidor para retê-las e empregar o respectivo valor na liquidação da dívida vencida. $\mathbb{S} 2^{\circ}$ No caso de operação de crédito junto a organismo financeiro internacional, ou a instituição federal de crédito e fomento para o repasse de recursos externos, a União só prestará garantia a ente que atenda, além do disposto no $\mathbb{S} 1^{\circ}$, as exigências legais para o recebimento de transferências voluntárias. $\mathbb{S} 3^{\circ}(\mathrm{VETADO}) ; \mathbb{S} 4^{\circ}(\mathrm{VETADO}) ; \mathbb{5} 5^{\circ}$ É nula a garantia concedida acima dos limites fixados pelo Senado Federal. $\mathbb{S} 6^{\circ}$ É vedado às entidades da administração indireta, inclusive suas empresas controladas e subsidiárias, conceder garantia, ainda que com recursos de fundos. $\mathbb{S} 7^{\circ} \mathrm{O}$ disposto no $\mathbb{S} 6^{\circ}$ não se aplica à concessão de garantia por: I - empresa controlada a subsidiária ou controlada sua, nem à prestação de contragarantia nas mesmas condições; II - instituição financeira a empresa nacional, nos termos da lei. $\mathbb{8} 8^{\circ}$ Excetua-se do disposto neste artigo a garantia prestada: I - por instituições financeiras estatais, que se submeterão às normas aplicáveis às instituições financeiras privadas, de acordo com a legislação pertinente; II - pela União, na forma de lei federal, a empresas de natureza financeira por ela controladas, direta e indiretamente, quanto às operações de seguro de crédito à exportação. $\mathbb{S} 9^{\circ}$ Quando honrarem dívida de outro ente, em razão de garantia prestada, a União e os Estados poderão condicionar as transferências constitucionais ao ressarcimento daquele pagamento. $\mathbb{S} 10$. O ente da Federação cuja dívida tiver sido honrada pela União ou por Estado, em decorrência de garantia prestada em operação de crédito, terá suspenso o acesso a novos créditos ou financiamentos até a total liquidação da mencionada dívida.

52 Art. $5^{\circ}$ É vedado aos Estados, ao Distrito Federal e aos Municípios: (...) VI - em relação aos créditos decorrentes do direito dos Estados, dos Municípios e do Distrito Federal, de participação governamental obrigatória, nas modalidades de royalties, participações especiais e compensações financeiras, no resultado da exploração de petróleo e gás natural, de recursos hídricos para fins de energia elétrica e de outros recursos minerais no respectivo território, plataforma 
art. $9^{\circ 53}$, que versa sobre o valor do limite global de garantias concedidas pelos Estados, pelo Distrito Federal e pelos Municípios, (iii) ao art. $17^{54}$, que veda a contratação de operação de crédito em que seja prestada garantia ao Estado, ao Distrito Federal ou ao Município por instituição financeira por ele controlada, (iv) ao art. $18^{55}$, que indica os requisitos para a concessão de garantia, pelos Es-

continental ou zona econômica exclusiva: a) ceder direitos relativos a período posterior ao do mandato do chefe do Poder Executivo, exceto para capitalização de Fundos de Previdência ou para amortização extraordinária de dívidas com a União; b) dar em garantia ou captar recursos a título de adiantamento ou antecipação, cujas obrigações contratuais respectivas ultrapassem o mandato do chefe do Poder Executivo. (...) $\mathbb{S} 4^{\circ}$ Excepcionalmente, os Estados, o Distrito Federal e os Municípios que sofreram redução nas receitas de que trata o inciso VI, inclusive de participações especiais, poderão contratar operações financeiras no limite das perdas apuradas entre a média recebida nos exercícios de 2013 e 2014 e a projeção para os anos de 2015 e 2016, dando em garantia os royalties a serem recebidos, contanto que o pagamento por tal contratação não comprometa mais de $10 \%$ (dez por cento) do valor total projetado em consequência da exploração dos mesmos recursos, por ano, sem a observância do disposto nas alíneas do referido inciso e no $\mathbb{S} 2^{\circ}$, bem como dos limites de que trata o art. $7^{\circ}$, ressaltando que a aplicação da totalidade do recurso observará a legislação aplicável a cada fonte de receita.

53 Art. $9^{\circ} \mathrm{O}$ saldo global das garantias concedidas pelos Estados, pelo Distrito Federal e pelos Municípios não poderá exceder a $22 \%$ (vinte e dois por cento) da receita corrente líquida, calculada na forma do art. $4^{\circ}$. Parágrafo único. O limite de que trata o caput poderá ser elevado para $32 \%$ (trinta e dois por cento) da receita corrente líquida, desde que, cumulativamente, quando aplicável, o garantidor: I - não tenha sido chamado a honrar, nos últimos 24 (vinte e quatro) meses, a contar do mês da análise, quaisquer garantias anteriormente prestadas; II esteja cumprindo o limite da dívida consolidada líquida, definido na Resolução n. 40, de 2001, do Senado Federal; III - esteja cumprindo os limites de despesa com pessoal previstos na Lei Complementar n. 101, de 2000; IV - esteja cumprindo o Programa de Ajuste Fiscal acordado com a União, nos termos da Lei n. 9.496, de 1997. (NR)

54 Art. 17. É vedada a contratação de operação de crédito em que seja prestada garantia ao Estado, ao Distrito Federal ou ao Município por instituição financeira por ele controlada.

55 Art. 18. A concessão de garantia, pelos Estados, pelo Distrito Federal e pelos Municípios, a operações de crédito interno e externo exigirá: I - o oferecimento de contragarantias, em valor igual ou superior ao da garantia a ser concedida; II - a adimplência do tomador relativamente a suas obrigações para com o garantidor e as entidades por ele controladas. $\mathbb{S} 1^{\circ}$ Consideram-se inadimplentes os tomadores com dívidas vencidas por prazo igual ou superior a 30 (trinta) dias e não renegociadas. $\$ 2^{\circ} \mathrm{A}$ comprovação do disposto no inciso II será feita por meio de certidão do Tribunal de Contas a que esteja jurisdicionado o garantidor ou, alternativamente, mediante declaração fornecida pelo Estado, Distrito Federal ou Município que estiver concedendo a garantia, diretamente ou por meio do agente financeiro que estiver operacionalizando a concessão da garantia. $\mathbb{S} 3^{\circ}$ Não será exigida contragarantia de órgãos e entidades que integrem o próprio Estado, o Distrito Federal, ou o Município, conforme definido no art. $2^{\circ}$ desta Resolução. 
tados, pelo Distrito Federal e pelos Municípios, a operações de crédito interno e externo, e (v) ao art. $47^{56}$, que permite, na linha do art. 40 da Lei de Responsabilidade Fiscal, a vinculação de receitas para a prestação de garantia ou contragarantia à União e suas autarquias e fundações.

Estabelecido o panorama normativo a respeito do oferecimento de garantias nos contratos de financiamento, adentra-se ao enfrentamento da possibilidade de oferecimento de receitas oriundas do FPE e do FPM pelos Estados, pelo Distrito Federal e pelos Municípios.

Pela leitura e interpretação dos dispositivos aplicáveis, entende-se que, regra geral, há vedação aos Estados, ao Distrito Federal e aos Municípios de oferecerem como garantia de financiamentos a receita de impostos de suas competências tributárias.

Contudo, em operações de crédito realizadas pelos Estados, pelo Distrito Federal e pelos Municípios diretamente com a União, as pessoas políticas podem dar em garantia (i) as receitas próprias geradas pelos impostos inseridos na sua competência tributária, (ii) os recursos elencados nos artigos 157 e 158 da Constituição Federal, e (iii) os recursos do FPE e do FPM.

$\mathrm{Na}$ obtenção de financiamentos junto a instituições financeiras federais, os recursos do FPE e do FPM, pela leitura da primeira parte do inciso IV do art. 167 da Constituição Federal, podem ser dados em garantia. A diferença perante as operações de crédito realizadas diretamente com a União é que esta pessoa política pode, constitucionalmente, se apropriar diretamente dos recursos dados em garantia na hipótese de inadimplemento, ao passo que nas operações realizadas com instituições financeiras federais a garantia será meramente contratual, cabendo a essas entidades a sua execução em juízo.

Neste sentido, vale trazer ao debate o conteúdo do Parecer n. 2/2018/Gab/ CGU/AGU ${ }^{57}$, da Advocacia Geral da União, que discorre a respeito do tema após provocação da Caixa Econômica Federal:

\footnotetext{
$\mathbb{S} 4^{\circ} \mathrm{O}$ Estado, o Distrito Federal ou o Município que tiver dívida honrada pela União ou por Estado, em decorrência de garantia prestada em operação de crédito, não poderá contratar novas operações de crédito até a total liquidação da mencionada dívida.

56 Art. 47. É permitida a vinculação de receitas próprias geradas pelos impostos a que se referem os arts. 155 e 156, e dos recursos de que tratam os arts. 157, 158 e 159, I, a e b, e II, da Constituição Federal, para a prestação de garantia ou contragarantia à União e suas autarquias e fundações.

57 Parecer n. 2/2018/Gab/CGU/AGU - NUP: 00400.000266/2018-87 - INTERESSADA: Caixa Econômica Federal. ASSUNTO: Oferecimento dos Fundos de Participação dos Estados e dos Municípios a título de garantia em operações de crédito celebradas entre entes subnacionais e instituições financeiras federais.
} 
31. Como se percebe, o texto constitucional permite que a União aceite como garantia e contragarantia os recursos repassados ao FPE e ao FPM com base nos incisos I, alíneas a e b, e II do art. 159, podendo, em caso de inadimplência, satisfazer diretamente seus créditos por meio da apropriação desses valores.

32. Logo, podem os entes subnacionais, quando celebram contrato com a União, oferecer de forma livre e espontânea suas quotas nos respectivos fundos como garantia ou contragarantia e, nesse caso, a União, por expressa autorização constitucional, pode honrar e amortizar o débito em caso de não cumprimento da obrigação contratual.

33. Situação diferente ocorre quando as quotas dos fundos de participação são oferecidas a título de garantia ou contragarantia em operação com outros sujeitos que não a União. Nessa hipótese, os entes subnacionais, devidamente autorizados por lei estadual ou local, oferecem um determinado percentual das quotas dos fundos de participação apenas como garantia contratual.

Na conclusão do seu parecer, a Advocacia Geral da União reforça a hipótese de que os recursos do FPE e do FPM podem ser oferecidos em garantia de financiamentos a instituições financeiras federais, a despeito de eventuais riscos de crédito atrelados a esta hipótese:

44. Realizadas as considerações acima, conclui-se que, nos termos do art. 167 , IV e $\mathbb{4} 4^{\circ}$, da CF, os recursos vinculados a fundos de participação, ofertados pelos Estados, Distrito Federal e Municípios, podem ser aceitos como garantia nas operações celebradas por entes subnacionais com as instituições financeiras federais.

45. Quanto aos eventuais riscos apontados pela Secretaria do Tesouro Nacional, nada impede que esse órgão, dada a sua atribuição atinente ao equilíbrio financeiro do Tesouro Nacional e à administração das dívidas públicas mobiliária e contratual, proponha futuros instrumentos de equalização do cenário apresentado.

46. A adoção de medidas que na prática se traduzam em vedação de acesso ao crédito pelos entes subnacionais, sem amparo no texto constitucional, geraria uma situação de desequilíbrio federativo igualmente não desejável, ofensiva à organização político-administrativa assegurada no art. 18 da

Ementa: escopo da manifestação jurídica. Interpretação da Constituição e demais atos normativos a ser uniformemente seguida. possibilidade de oferecimento dos fundos de participação dos estados e dos municípios a título de garantia em operações de crédito celebradas entre entes subnacionais e instituições financeiras. Interpretação do art. 167, inciso IV e $\mathbb{S} 4^{\circ}$, da Constituição. Publicado no Diário Oficial da União em 04 de abril de 2018. 
Constituição, comprometendo, inclusive, o princípio da segurança jurídica e o seu corolário do ato jurídico perfeito.

47. A interpretação do texto constitucional deverá considerar a autonomia dos entes subnacionais, notadamente, na utilização dos recursos do FPM e FPE que lhe são próprios, sem desconsiderar a importância de se buscar o melhor equilíbrio entre a utilização dessa garantia e a situação fiscal do ente federativo.

Assim, diante do exposto, entende-se ser juridicamente possível o oferecimento de recursos do FPM e do FPE como garantias, pelos Estados, pelo Distrito Federal e pelos Municípios, em contratos de financiamento celebrados com instituições financeiras federais, tendo essa garantia força contratual, ou seja, não sendo possível às instituições financeiras federais executarem diretamente essa garantia sem a intermediação do Poder Judiciário.

\section{DAS CONSEQUÊNCIAS JURÍDICAS PELA CONTRATAÇÃO IRREGULAR DO FINANCIAMENTO}

A concessão de financiamento aos Estados, aos Municípios e ao Distrito Federal sem a observância das condições e limites pertinentes a este tipo de operação gera consequências jurídicas de diversas matizes.

Sob o espectro constitucional, efetivada a contratação de financiamento por parte de Estado, Município ou pelo Distrito Federal, a Constituição Federal prevê algumas formas de salvaguardar o pactuado, no intuito de evitar as danosas consequências que o inadimplemento pode causar.

Uma dessas ferramentas é a intervenção. Conforme preceitua Pedro Lenza ${ }^{58}$, o art. 18 da Constituição Federal estabelece que Municípios, Estados, o Distrito Federal e a União formam a estrutura política administrativa da República, sendo todos autônomos. Entretanto, excepcionalmente, a própria Carta Constitucional prevê situações de anormalidade em que a autonomia do ente federado pode ser temporariamente suprimida: tratam-se de hipóteses de intervenção.

Nesse cenário, passa-se a analisar se a inadimplência de Município, Estado ou Distrito Federal em financiamento celebrado com instituição financeira federal pode gerar intervenção, nos termos do art. 34, V, "a" da Constituição Federal ${ }^{59}$.

58 LENZA, Pedro. Direito Constitucional esquematizado. 16. ed. São Paulo: Saraiva, 2012. p. 466.

59 Art. 34. A União não intervirá nos Estados nem no Distrito Federal, exceto para: (...) V - reorganizar as finanças da unidade da Federação que: a) suspender o pagamento da dívida fundada por mais de dois anos consecutivos, salvo motivo de força maior; (...) 
O conceito legal de dívida fundada não é pacífico, pois uma série de dispositivos legais o conceituam de forma distinta. O art. 98 da Lei n. 4.320/1964 ${ }^{60}$ preceitua que a dívida fundada compreende os compromissos de exigibilidade superior a doze meses, contraídos para atender a desequilíbrio orçamentário ou o financiamento de obras e serviços públicos.

Já o art. $115, \mathbb{S} 2^{\circ}$ do Decreto n. 93.872/198661 a define como sendo os compromissos de exigibilidade superior a 12 (doze) meses contraídos mediante emissão de títulos ou celebração de contratos para atender a desequilíbrio orçamentário, ou a financiamento de obras e serviços públicos, e que dependam de autorização legislativa para amortização ou resgate.

Por sua vez, a Lei de Responsabilidade Fiscal a conceitua como sendo montante total, apurado sem duplicidade, das obrigações financeiras do ente da Federação, assumidas em virtude de leis, contratos, convênios ou tratados e da realização de operações de crédito, para amortização em prazo superior a doze meses, nos termos do art. 29, $\mathrm{I}^{62}$.

Apesar da disparidade de conceitos legais, parece-nos plausível enquadrar o financiamento como item integrante da dívida fundada, desde que estabeleça compromissos financeiros superiores a doze meses. A conclusão é alcançada ao se notar que o elemento comum às três definições legais é a assunção de obrigação financeira por mais de doze meses.

A despeito da categorização do financiamento como um dos elementos que compõe a dívida fundada, acredita-se que o simples inadimplemento de um financiamento não gera a intervenção, mesmo que a inadimplência perdure dois anos e não haja motivo de força maior.

Nos termos dos dispositivos constitucionais, o que gera a intervenção é o não pagamento da dívida fundada como um todo e não um de seus componentes.

${ }^{60}$ Art. 98. A dívida fundada compreende os compromissos de exigibilidade superior a doze meses, contraídos para atender a desequilíbrio orçamentário ou a financeiro de obras e serviços públicos.

${ }^{61}$ Art. 115. A dívida pública abrange a dívida flutuante e a dívida fundada ou consolidada. (...) $\$ 2^{\circ}$ A dívida fundada ou consolidada compreende os compromissos de exigibilidade superior a 12 (doze) meses contraídos mediante emissão de títulos ou celebração de contratos para atender a desequilíbrio orçamentário, ou a financiamento de obras e serviços públicos, e que dependam de autorização legislativa para amortização ou resgate.

62 Art. 29. Para os efeitos desta Lei Complementar, são adotadas as seguintes definições: I - dívida pública consolidada ou fundada: montante total, apurado sem duplicidade, das obrigações financeiras do ente da Federação, assumidas em virtude de leis, contratos, convênios ou tratados e da realização de operações de crédito, para amortização em prazo superior a doze meses. 
Conforme leciona Uadi Lammêgo Bulos ${ }^{63}$, o uso do instrumento é excepcional, limitando-se, necessariamente, às hipóteses taxativamente previstas na Carta Constitucional.

Logo, em razão de sua natureza excepcional, as disposições sobre a intervenção devem ser interpretadas restritivamente, sendo vedada a utilização de método interpretativo extensivo ou analógico.

Portanto, em razão da literalidade do texto constitucional e pela necessária hermenêutica restritiva natural às normas excepcionais, chega-se à conclusão de que o simples inadimplemento de um financiamento não gera a possibilidade de intervenção.

No âmbito infraconstitucional, de acordo com o item 22 do MIP ${ }^{64}$ as consequências jurídicas podem atingir o próprio contrato ou os responsáveis por sua celebração em desacordo com a legislação.

O contrato irregularmente celebrado é nulo e o principal da dívida deverá ser devolvido à instituição financeira, sendo vedado o pagamento de juros e demais encargos financeiros, nos termos do art. $33, \mathbb{S} 1^{\circ}$ da Lei de Responsabilidade Fiscal.

Nos termos do art. $33, \mathbb{S} \mathbb{S} 2^{\circ}$ e $3^{\circ}$ combinados com o art. $23, \mathbb{S} 3^{\circ}$, todos da Lei de Responsabilidade Fiscal ${ }^{65}$, a devolução de recursos que não ocorrer no próprio exercício de recebimento dos recursos deverá ser consignada em reserva específica na lei orçamentária para o exercício seguinte. Enquanto não efetuado o cancelamento da operação, a devolução dos recursos ou a constituição de reserva para o ano seguinte, $o$ ente federativo não poderá: (i) receber transferências voluntárias; (ii) obter garantia, direta ou indireta, de outro ente; e (iii) contratar operações de crédito, ressalvadas as destinadas ao refinanciamento da dívida mobiliária e as que visem à redução das despesas com pessoal.

${ }^{63}$ BULOS, Uadi Lammêgo. Direito Constitucional ao alcance de todos. 3. ed. São Paulo: Saraiva, 2011. p. 493.

${ }^{64}$ Disponível em: https://conteudo.tesouro.gov.br/manuais/mip/361-22-punicoes-pela-contratacao-irregular-de-operacoes-de-credito. Acesso em 01/07/2018.

${ }^{65}$ Art. 23. Se a despesa total com pessoal, do Poder ou órgão referido no art. 20, ultrapassar os limites definidos no mesmo art. , sem prejuízo das medidas previstas no art. 22, o percentual excedente terá de ser eliminado nos dois quadrimestres seguintes, sendo pelo menos um terço no primeiro, adotando-se, entre outras, as providências previstas nos $\mathbb{S} 3^{\circ}$ e $4^{\circ}$ do art. 169 da Constituição. (...) $\mathbb{S} 3^{\circ}$ Não alcançada a redução no prazo estabelecido, e enquanto perdurar o excesso, o ente não poderá: I - receber transferências voluntárias; II - obter garantia, direta ou indireta, de outro ente; III - contratar operações de crédito, ressalvadas as destinadas ao refinanciamento da dívida mobiliária e as que visem à redução das despesas com pessoal. 
Sob a ótica administrativa, a Lei n. 8.429/1992, em seu art. 10, inciso VI ${ }^{66}$, elenca como ato de improbidade administrativa a realização, por parte de agente público, de operação financeira sem observância das normas legais e regulamentares, ou a aceitação de garantia insuficiente ou inidônea.

Sob a ótica penal, notamos que no início dos anos 2000 o tema das finanças públicas, notadamente em seu aspecto de controle da dívida pública, ganhou notoriedade e importância na agenda do país, fazendo com que diversas condutas tidas como danosas ao erário público fossem alçadas a tipos penais. Para tanto, a Lei n. 10.028/2000 introduziu no Título XI do Código Penal o Capítulo IV, intitulado "DOS CRIMES CONTRA AS FINANÇAS PÚBLICAS”.

Logo, após o advento desta Lei, a concessão de financiamento aos Estados, aos Municípios e ao Distrito Federal sem a observância das condições e limites pertinentes passou a ser crime, tipificado no art. 359-A do Código Penal ${ }^{67}$.

A mesma Lei modificou a Lei n. 1.079/1950 e o Decreto-Lei n. 201/1967, normativos que definem os crimes de responsabilidade e regulam o respectivo processo de julgamento, sendo o primeiro aplicável aos governadores de Estado e do Distrito Federal, e o segundo aos prefeitos dos Municípios.

Na Lei n. 1.079/1950 foi introduzido o item 9 ao art. $10^{68}$, já no Decreto-Lei n. 201/1967 inseriu-se o inciso XX ao art. $1^{069}$. Nos termos dos dispositivos, o prefeito ou governador que ordenar ou autorizar o financiamento com instituição

${ }^{66}$ Art. 10. Constitui ato de improbidade administrativa que causa lesão ao erário qualquer ação ou omissão, dolosa ou culposa, que enseje perda patrimonial, desvio, apropriação, malbaratamento ou dilapidação dos bens ou haveres das entidades referidas no art. $1^{\circ}$ desta lei, e notadamente: (...) VI - realizar operação financeira sem observância das normas legais e regulamentares ou aceitar garantia insuficiente ou inidônea.

${ }^{67}$ Art. 359-A. Ordenar, autorizar ou realizar operação de crédito, interno ou externo, sem prévia autorização legislativa: Pena - reclusão, de 1 (um) a 2 (dois) anos. Parágrafo único. Incide na mesma pena quem ordena, autoriza ou realiza operação de crédito, interno ou externo: I - com inobservância de limite, condição ou montante estabelecido em lei ou em resolução do Senado Federal; II - quando o montante da dívida consolidada ultrapassa o limite máximo autorizado por lei.

68 Art. 10. São crimes de responsabilidade contra a lei orçamentária: (...) 9) ordenar ou autorizar, em desacordo com a lei, a realização de operação de crédito com qualquer um dos demais entes da Federação, inclusive suas entidades da administração indireta, ainda que na forma de novação, refinanciamento ou postergação de dívida contraída anteriormente.

${ }^{69}$ Art. $1^{\text {o }}$ São crimes de responsabilidade dos Prefeitos Municipal, sujeitos ao julgamento do Poder Judiciário, independentemente do pronunciamento da Câmara dos Vereadores: (...) XX ordenar ou autorizar, em desacordo com a lei, a realização de operação de crédito com qualquer 
financeira federal em desacordo com a legislação de regência, cometerá crime de responsabilidade orçamentária, passível de pena de impedimento.

\section{CONCLUSÃO}

O presente trabalho teve o objetivo de expor o panorama geral das regras jurídicas aplicáveis à concessão de financiamento a Estados, Municípios e Distrito Federal por parte de instituições financeiras federais.

Verificamos que o conjunto de normas jurídicas é complexo e requer um esforço interpretativo sistemático para se depreender o regime aplicável ao caso concreto. O Manual para Instrução de Pleitos emitido pela Secretaria do Tesouro Nacional representa uma medida salutar para organizar o entendimento do tema, mas não encerra, por si só, todas as variáveis e regras aplicáveis à concessão de financiamento.

Diante da sensibilidade do tema, que representa uma interlocução financeira entre as instituições financeiras federais (controladas pela União) e as demais pessoas políticas, é natural que a sua regulamentação seja extensa e detalhada. Contudo, para uma melhor operacionalização das operações de financiamento, examinamos que seria necessária certa flexibilização do regime jurídico.

A inovação legal trazida pelo art. 10 da Lei Complementar n. 148/2014 e pela Portaria MF n. 413/2016 demonstram uma tendência nesse sentido, mas os valores autorizados ainda estão pequenos diante da praxe de operações de financiamento realizadas pelas pessoas políticas, seja para obras de infraestrutura, seja para o desenvolvimento de projetos de pesquisa, desenvolvimento e inovação.

\section{REFERÊNCIAS}

ALEXANDRINO, Marcelo; PAULO, Vicente. Direito administrativo descomplicado. 21. ed. São Paulo: Método, 2013.

BALEEIRO, Aliomar. Direito tributário brasileiro. Rio de Janeiro, Editora Forense, 2008.

BULOS, Uadi Lammêgo. Direito constitucional ao alcance de todos. 3. ed. São Paulo: Saraiva, 2011.

CONTI, José Mauricio. Arts. 32 a 39. In: MARTINS, Ives Gandra et al. (Org.). Comentários à Lei de Responsabilidade Fiscal. 5. ed. São Paulo: Saraiva, 2011.

um dos demais entes da Federação, inclusive suas entidades da administração indireta, ainda que na forma de novação, refinanciamento ou postergação de dívida contraída anteriormente. 
CONTI, José Mauricio. Direito financeiro na Constituição de 1988. São Paulo: Oliveira Mendes.

CRUZ, Flavio da et al (Org.). Lei de responsabilidade fiscal comentada: Lei Complementar n. 101, de 4 de maio de 2000. 5. ed. São Paulo: Atlas, 2006.

HARADA, Kiyoshi. Responsabilidade fiscal: Lei Complementar n 101/2000 comentada e legislação correlata anotada. São Paulo: Juarez de Oliveira, 2002.

LENZA, Pedro. Direito constitucional esquematizado. 16. ed. São Paulo: Saraiva, 2012.

OLIVEIRA, Regis Fernandes de. Curso de direito financeiro. 7. ed. São Paulo: Revista dos Tribunais, 2015.

PISCITELLI, Tathiane. Direito financeiro esquematizado. 3. ed. São Paulo: Método, 2012 .

SCHOUERI, Luís Eduardo. Direito tributário. São Paulo: Saraiva, 2011.

SILVA, Ives Gandra da (Org.). Comentários à lei de responsabilidade fiscal. 5. ed. São Paulo: Saraiva, 2011.

ULHOA, Fabio Coelho. Manual de direito comercial. 23. ed. São Paulo: Saraiva, 2011. 
